The Canadian Journal of Higher Education La revue canadienne d'enseignement supérieur

Volume XXXII, No. 3, 2002 pages 85-110

\title{
The New Entrepreneurship in Higher Education: The Impact of Tuition Increases at an Ontario University ${ }^{*}$
}

\section{LINDA QUIRKE \& SCOTT DAVIES}

McMaster University

\section{ABSTRACT}

Recent increases in university tuition fees are part of a new entrepreneurial trend in higher education in which institutions are expected to generate more of their own revenue. We examine the effects of this trend on access to universities for students of lower socioeconomic origins, and identify a series of cross cutting pressures. On the one hand, tuition fees pose an obvious financial barrier for these students, whom researchers have shown to be relatively cost-sensitive and debt-averse. On the other hand, the demand for university education among youth from all backgrounds remains buoyant, and student cultures may be increasingly resigned to accepting large debts to finance their schooling. We then examine empirical evidence from two surveys from the University of Guelph, along with some supplementary sources. We find that the representation of students from low socioeconomic backgrounds fell substantially during a decade of rising tuition costs. In discussing this finding, we link the phenomena of higher and de-regulated tuition to the new entrepreneurship, and argue that it has the potential to increasingly stratify Canadian higher education.

* The authors would like to thank lan McMillan and, in particular, the late Sid Gilbert for their assistance with earlier versions of this work. 


\section{RÉSUMÉ}

Les augmentations récentes des frais de scolarité à l'université font partie d'une tendance à un «nouvel entrepreneurship» dans l'enseignement supérieur, tendance à l'intérieur de laquelle on s'attend à ce que les institutions génèrent leurs propres revenus. Dans cet article, nous nous intéressons aux effets de cette orientation sur l'accès aux universités des étudiants d'origine socioéconomique modeste et constatons une série de tendances opposées aux coupures. D'une part, les frais de scolarité créent une barrière financière évidente pour ces étudiants qui, selon les démonstrations des chercheurs, sont relativement sensibles à l'évolution des coûts et opposés à l'endettement. D'autre part, la demande d'un niveau universitaire d'éducation demeure soutenue chez les jeunes de toutes les provenances, et les cultures étudiantes peuvent se résigner de plus en plus à accepter de grosses dettes pour financer leurs études. Nous examinons ensuite les preuves empiriques provenant de deux enquêtes de l'Université de Guelph qui confirment nos prétentions, de même que quelques autres sources. Nous constatons que la représentation des étudiants venant des milieux socioéconomiques modestes a considérablement diminué durant cette décennie des coûts croissants des frais de scolarité. Dans la discussion de ces résultats, nous associons ce phénomène de frais de scolarité plus élevés et déréglés au nouvel entrepreneurship académique, et soutenons qu'il possède un potentiel de clivage de plus en plus grand en enseignement supérieur canadien.

\section{INTRODUCTION}

A new climate surrounds postsecondary education. In Canada and in other industrialized nations, universities have increasingly adopted entrepreneurial, market-like traits. Now facing a less certain climate of government funding, they are seeking, with encouragement from politicians and business representatives, other sources of revenue. With fewer assurances that the state will continue to offer generous block-grants, universities are creating new opportunities to raise funds, whether by aligning themselves with business, conducting lucrative research aimed at 
commercial innovations, or trying to maximize existing sources of revenue (Fisher \& Rubenson, 1988; Slaughter \& Leslie, 1997). To secure these resources, universities and individual faculty members are adopting competitive, entrepreneurial behaviour, virtually unseen in previous decades, in a process dubbed "academic capitalism" (Slaughter \& Leslie, 1997). Governments and business leaders are urging universities to "keep what the market will pay for" (Marchak 1996, p. 654).

These institutional changes reflect a pervasive ideological shift in the delivery of traditional public services (Furlong \& Cartmel, 1997; Nelson, 1995). Postsecondary education, like services such as health care, is increasingly viewed through a "free market" lens. Market values are being incorporated into the system as governments increasingly see university education as a private consumer product, and contend that its users - students - ought to shoulder a greater burden of its costs. Since dozens of studies show that graduates attain better than average jobs and incomes, governments feel justified in transferring the cost of higher education to individuals and their families (Anisef, Bell \& Sweet, 2001).

\section{Rising and Deregulated Tuition}

One obvious source of secure, independent revenue for universities is to increase their tuition fees. This has become an international phenomenon (Dill, 2001), and Canada is no exception. Once criticized as a barrier to access, raised fees are now heralded in this country as a valid source of secure revenue in the new climate.' Provincial governments, particularly in Ontario, have recently permitted universities to raise general undergraduate tuition, and have deregulated fees for certain specialized programs. As a result, Canadian tuition fees have risen dramatically in the past decade.

In 2001, average undergraduate arts tuition in Canada reached $\$ 3,452$, twice the 1991-92 average of $\$ 1,714$ (Statistics Canada, 2001). Compared to previous decades, Canadian students now shoulder a greater portion of the financial burden of attending university. Moreover, some provincial governments are delegating the authority to set fees to individual universities. The Ontario government in 1998 allowed institutions to deregulate fees for professional schools such as medicine, dentistry, and 
business, resulting in a doubling to quadrupling of fees from 1995-96 levels (Statistics Canada, 1999b).

These rising expenses have outstripped the fiscal capacities of most Canadian families. Tuition rose $125 \%$ between 1980-98 while average family income grew by only $1 \%$ (Clark, 1998; Statistics Canada, 1998). It is estimated that fees are now less affordable to an average family than at any time during the previous 20 years (Little, 1997). Nearly three in four parents claim to be concerned about the cost of education (Ipsos-Reid, 2001). More than one in three Canadian university students report being "very concerned" about not having enough money to complete their studies (Canadian Undergraduate Survey Consortium, 1998). In a study of 23 universities across Canada, students rated "keeping tuition increases at or below inflation" as the issue requiring the most improvement (Canadian Undergraduate Survey Consortium, 1999).

To complicate matters, Canada, like other countries, is reducing nonrepayable government student assistance, like bursaries and grants in favour of loans. As a result, students' reliance on loans and debt financing has increased substantially (Clark, 1998; Plager \& Chen, 1999). Average student debts in Ontario have doubled since grants were eliminated in 1992-93 (Council of Ontario Universities, 1999). Students owe more money to loan programs than in the past, with $48 \%$ of university students now taking on debt (Anisef et al., 2001). The class of 1995 borrowed more from student loan programs than any group of graduates in the past 15 years (Clark, 1998). The average student debt is approximately $\$ 11,000$, with roughly one in four students claiming difficulty in repaying (Anisef et al., 2001). These trends appear set to continue, at least in the short run, within the new climate of higher education.

The new academic entrepreneurship, in the form of tuition increases, not only has profound implications for equality of access to higher education, but also for the sociological study of education. The link between socioeconomic background and educational attainment has been one of the most studied topics in sociology since the 1960s. A sizable body of research, both international and Canadian, has consistently shown that students from more affluent backgrounds fare better 
than their less affluent counterparts. ${ }^{2}$ Indeed, researchers have repeatedly found little or no change over time in the relationship between educational attainment and socioeconomic status.

This relationship needs to be understood in a broader context, however. The story of higher education in the latter half of the $20^{\text {th }}$ century was that of expansion. Enrolment in universities in a variety of nations, particularly Canada, grew exponentially. All of society's strata shared in this expansion, as youth from all backgrounds boosted their educational attainment. Overall access to higher education improved immensely in the post-WWII era, though not all strata have shared equally in this expansion. As more and more students entered universities, low-SES students remained under-represented.

Recent data suggest that the relationship between social class and postsecondary attendance may have weakened in the 1970s and 1980s. Postsecondary participation rates of those in the lowest income quintiles began to converge with those of the highest income quintiles (Christofides, Cirello, \& Hoy, 2001). However, these data extend only to 1993, and do not cover the 'high-tuition' period of the late 1990s. It remains to be seen if this convergent trend was reversed throughout this period of heightened tuition fees.

The new academic entrepreneurship suggests that we are on the brink of a new era in higher education, one marked by market values, revenue-consciousness, and higher tuition. In this paper we examine one immediate impact of this new academic culture: Have rapid rises in tuition in recent years altered access to university? Though university attendance is already marked by social class disparities, are students from low-SES backgrounds now even less represented at universities? Since these students are less able to rely on parents or non-repayable financial support, are they willing to endure loans and subsequent debt to attend university? The empirical answers to these questions are not entirely clear due to a series of cross-cutting trends that we discuss next. 


\section{CROSSCUTTING FORCES: COST SENSITIVITY VERSUS RISING DEMAND FOR CREDENTIALS}

Over the past few decades, a variety of theories have been developed to explain the persistence of socioeconomic disparities in education, focussing variously on economics, culture, or school biases (for a summary, see Davies, 1999). None, however, discount the stark role of finances in education. John Porter (1973) and his colleagues concluded almost 30 years ago that "money matters," and decades of subsequent research in the sociology of education has revealed a robust empirical relationship between class and attainment. From this imposing literature one can reason that rising tuition can only exacerbate these disparities. Whether in the form of across-the-board increases or in the form of deregulated fares for professional programs, these hikes present an obvious barrier to low-income families.

Some recent studies suggest that students from low-SES backgrounds may be most disadvantaged in this new climate of higher education. While families from all strata spent more on postsecondary education between 1992 and 1998, low-income families were especially hard hit by dwindling disposable incomes (Anisef et al., 2001). Families with middle and lower incomes are making disproportionally greater financial sacrifices to attend university (Statistics Canada, 2000b). A recent study suggests that, in response to deregulation, medical students at the University of Western Ontario are coming from increasingly affluent families. The study found that the average gross family income of first-year medical students rose from $\$ 80,000$ to $\$ 140,000$ between 1998 and 2000, while the proportion of such students from families earning less than $\$ 60,000$ dropped from $36 \%$ to $15 \%$ (Fine, 2001).

Further, there is empirical literature on willingness to pay hefty fees and education-related debts. Among students, the prospect of incurring large debt to attend university is most discouraging to those from disadvantaged backgrounds (Anisef et al., 2001). These students are more sensitive than higher-income students to tuition increases and the cost of attending university (Cameron, 1997; Delaney, 1998; Heller, 1997). Likewise, among parents, both ability and willingness to pay for their 
children's education increases with social class. American parents with higher incomes and education feel more duty-bound to assume financial responsibility for their children's schooling, to the point of incurring large debts (Miller, 1997; Steelman \& Powell, 1991).

However, there are other reasons that could lead one to expect that lower SES background students may continue to attend university, despite tuition increases. In general, the demand for university credentials has remained high, despite their rising cost. Recent data show some growth between 1991 and 1997 in new, first-year enrolments (as a percentage of the 19-year-old population; see Bouchard \& Zhao, 2000). Universities are planning for more expansion, as a greater proportion of high school graduates are expected to enter higher education in the coming years. Surveys show that the vast majority of Canadian parents now expect their children to attend a postsecondary institution (Sweet et al., 2002).

A primary reason for this buoyant demand for credentials is that degrees remain a prime currency for access to good jobs. Employers in the new "knowledge" economy are favouring — rightly or wrongly — better educated workers. Further, the value of credentials accumulated in earlier decades, like the high school diploma, is declining. This devaluation generates further demand for university degrees, creating more and more competition to enter the postsecondary system. The evidence suggests that university graduates, even if underemployed (Livingstone, 1999), continue to earn a sizable wage premium, compared to graduates and dropouts from community colleges and high schools. For instance, recent university graduates earned roughly $\$ 32,000$, while college and trade/vocational school graduates earned yearly salaries of $\$ 25,700$ and $\$ 23,400$ respectively (Bouchard \& Zhao, 2000; see also Guppy \& Davies, 1998). ${ }^{3}$

What is particularly salient to less affluent youth is that the shift to an increasingly service-oriented labour market has reduced traditional manual or blue-collar opportunities for those without postsecondary credentials (Nelson, 1995). Since opportunities for youth who lack higher education appear to be lessening, it is a less viable option for them to forgo university. With fewer options, academically-able working class youth may now be willing to endure large debt loads to attend university, more than in the past, and thus continue to attend university in similar proportions. 
Indeed, a "debt culture" norm may have emerged among Canadian students. This is certainly the implicit premise of policy makers who see repayable loans as a way to offset recent boosts in tuition costs. According to this reasoning, youth are slowly accepting a new cultural frame in which to view educational costs. In previous decades, many youth could view these costs within a "summer job" conception, to be paid in a relatively short time span. Fees could often be paid without long-term planning and high debts, especially by commuting students who remained at home with their parents. However, now many, if not most, students are forced to view these costs in terms of a "finance model," which requires more planning and strategy, a longer repayment period, and the assuming of substantial debt loads.

Further, some policy makers also see scholarships as a tool of equity. Canadian universities have recently boosted scholarships. Between 1993-94 and 1998-99, spending on scholarships and bursaries climbed by $68 \%$, to roughly $\$ 370$ million (Statistics Canada, 2000c). For instance, the University of Guelph increased the amount of nonrepayable student aid from $\$ 3.2$ million in $1992-93$ to $\$ 7.6$ million in 1998-99. The University of Toronto guaranteed in 1998 that no attending student would be prevented from finishing his or her degree for financial reasons. Such programs are publicized as having the potential to ameliorate problems of access. However, this approach has been widely criticized. American research indicates a persisting relationship between rising tuition and dropping student enrolment, in spite of financial assistance offers (Heller, 1997; Schmidt, 1998). Also, bursaries are used to recruit high-achieving students of any background, rather than focusing on financial need.

\section{RESEARCH QUESTIONS}

For the reasons listed above, the effect of recent tuition increases remains unclear. Many key issues need to be addressed: What is the impact of rapid increases in tuition on access in an era of increasing competition, rising enrolments, and a new loan culture? Are rising tuition costs further tilting an uneven playing field? There is now a 
dearth of large-scale and systematic data. Commonly cited Canadian studies are now dated (7-8 years old), and fail to capture the impact of tuition increases throughout the 1990s (Bouchard \& Zhao, 2000). In this paper we present recent data from one university that allow us to address three specific questions.

First, what is the impact of rising tuition on the representation of lower SES students in universities? With a few different data sources we explore the impact of rising tuition costs on the social class composition of a university. With dramatic increases in tuition, are students from lowincome families less represented? Our intent is not to assess the array of theories that attempt to explain persisting class disparities in education, but to document whether these disparities remained constant between the late 1980s and late 1990s, a time frame marked by tuition increases. We explore whether the representation of low-SES students changed in a sample of students for one university for which we have data, the University of Guelph. If the rising overall cost of attending university had no effect on access, then the proportion of young people from low-SES backgrounds attending university should remain relatively stable. To our knowledge, this is the first Canadian study to examine the impact of the general, across-the-board tuition increases that took place in the 1990s.

Second, do these trends vary among different types of universities? Our focus is on the University of Guelph, a residential institution that draws most of its students from beyond its local area. The total costs of attending such universities are quite high for those who do not live in the local area. In contrast, "commuter institutions" draw the majority of their students from their immediate locales, and are less expensive for those who may live nearby with their families. The University of Guelph draws more than $90 \%$ of its students from outside its local area, and accommodates more than 4,000 students in on-campus housing. While we expect a residential institution like Guelph to attract a larger than average proportion of higher-SES students, the issue is whether this over-representation changed in an era of rapid tuition increases. Since the University of Guelph did not become more residential in the period under study, 1987 to 1998 , it is reasonable to test whether the proportions of students from varying social class backgrounds remained 
relatively stable over a period of climbing tuition. While any conclusions we draw in this paper are speculative, there is little Canadian research that examines access to different types of universities.

Third, what are the subjective outcomes of these trends? Do lowSES students rely less on their parents, and more heavily on loans? Are they taking on more debt to attend university, and dropping a "summer job" conception of financing their education in favour of a "finance model," which involves assuming high levels of debt?

\section{METHODS}

This study uses several data sources. The primary data come from two quantitative surveys at the University of Guelph, a mid-size Ontario university. The Incoming Student Survey (ISS) has been administered each year since 1987 to first-year students on registration day. The survey produces samples of 1,100-1,400 responses, with a response rate of approximately $50 \%$. Students were asked to provide information about their parents' education and income. Parents' education was categorized into three levels: high school or less, some postsecondary, and a university degree or higher. Income was classified as either "low-income", a combined gross parental income of less than $\$ 40,000$, and "higher income", represented by incomes of $\$ 40,000$ and higher. ${ }^{4}$ Also, the ISS asks students about the sources of their educational funding (i.e., savings, financial assistance from parents, taking out loans, etc.), and the extent to which they are concerned about financing their education (i.e., "not concerned," "somewhat concerned," and "very concerned"). These responses were cross-tabulated by parental education and income to determine whether responses differ by social class.

The second Guelph survey, the Admitted Student Questionnaire (ASQ), was administered in 1993 and 1996 to students who were admitted, whether they enrolled or not. Response rates are high for those who later enrolled (67\%) and lower for those who did not enrol (48\%). Also, students were asked to rank the importance of qualities they associate with Guelph (i.e., reputation, cost of attending, etc.), compared to other universities, whether they rate the cost of attending the university as 
"expensive," and how offers of financial aid figured in their decision to attend. These ratings were cross-tabulated with parental income to ascertain whether students from different backgrounds were more or less "cost-sensitive" (the ASQ does not include questions about parental education levels).

Next, we compared the composition of the Guelph student body with those at universities across Canada. A 1998 study conducted at the University of Manitoba (Canadian Undergraduate Survey Consortium, 1998) asked first-year students in nineteen universities across Canada about the educational backgrounds of their parents. Also, these data were compared to the population of Ontario and Canadian males and females, aged 45-64, to determine if Guelph students were representative of the overall population of the province and of the country. We chose this age group to approximate the ages of parents of the vast majority of firstyear university students, who are usually 18 or 19 years of age. The education and income of these parent-aged adults were estimated from the census and the General Social Survey. While not a perfect control group, it allows us to compare the family background of Guelph students with that of the general population.

\section{FINDINGS}

\section{Changes in the Student Composition at the University of Guelph}

Tables 1 and 2 suggest that the social class composition of students at the University of Guelph changed substantially over time. Between 1987 and 1998, Guelph students were increasingly drawn from relatively affluent homes, and had parents with a modicum of formal education. They were less likely to have parents with relatively low levels of income and education (i.e., high school or less), compared to a decade earlier. In $1987,40 \%$ of first-year respondents came from families with a gross yearly income of $\$ 40,000$ or less. This was actually higher than the proportion $(33 \%)$ of Ontario families headed by someone aged 45-64 earning $\$ 40,000$ or less (Statistics Canada, 1986, 1994). But in 1998, only $16 \%$ of entering students were drawn from families in this category, 
Table 1

Percent of Students (count) from Low-Income Backgrounds* Entering the University of Guelph Compared to Percent of Low-Income Families in Ontario

$\begin{array}{llll} & 1987 & 1992 & 1998 / 96 \\ \text { University of Guelph } & 40 & 27(285) & 16 \\ \text { Ontario } & 33(295.6) & 24(229.9) & 23\end{array}$

* "Low-Income" refers to gross parental income of less than $\$ 40,000$. Guelph Ns unavailable for 1987 and 1998.

Source: Guelph Incoming Student Survey, 1987, 1992 and 1998; General Social Survey, 1987. 1992 and 1996; Statistics Canada (Ontario families with age of head 45-64 with income less than $\$ 40,000$ ) (Ontario numbers in thousands).

Table 2

Percent of Students (count) from Low-Income Backgrounds* Entering the University of Guelph Compared to Percent of Ontario Residents with Low Education

$\begin{array}{llll} & 1987 / 86 & 1992 / 91 & 1998 / 96 \\ \text { University of Guelph } & 52 & 38(457) & 27 \\ \text { Ontario } & 56(502.8) & 57(565.2) & 50(566.7)\end{array}$

* Based on father's education, high school or less.

Guelph Ns unavailable for 1987 and 1998. Ontario data unavailable for 1986, 1991, and 1996.

Source: Guelph Incoming Student Survey, 1987, 1992 and 1998; 1991 and 1996 census; Statistics Canada (Ontario males aged 45-64 with high school education or less) (Ontario numbers in thousands).

The Canadian Journal of Higher Education

Volume XXXII, No. 3, 2002 
which is less than the proportion (23\%) of all Ontario families in that category (see Table 1). Table 2, with data on parental education, shows that in $1987,52 \%$ of entering students' fathers had a high school education or less, which equals roughly the proportion among Ontario males aged 45-64 (the trend for mother's education is very similar). In 1998, however, only $27 \%$ of entering students' fathers had attended high school or less, compared with $50 \%$ of Ontario males aged $45-64$.

Whether looking at parents' income or education, Guelph students from low-SES backgrounds went from being slightly under-represented in the late 1980s to being substantially under-represented a decade later. This is a dramatic change in social class composition in a relatively short time, suggesting that the composition of incoming cohorts of students increasingly diverged from the general population between the late 1980 s and late 1990s.

\section{Comparing Guelph to Other Universities}

Table 3 suggests that the under-representation of low-SES students is not unique to Guelph; it is indeed a national phenomenon. While this is to be expected, given the findings of a longstanding body of Canadian research, these data also suggest that Guelph is a relatively exclusive university. While at other universities, one third of students' fathers had only a high school education or less in 1998, the corresponding figure for Guelph students' fathers is $27 \%$ (compared to $50 \%$ of males aged 45-64 in Canada; similar trends are seen based on mother's education). These data suggest that students from low-education backgrounds are substantially under-represented at Canadian universities, and particularly so at the University of Guelph.

\section{Subjective Measures: Low-SES Students are Borrowing and Worrying More}

Our data in Table 4 indicate that sensitivity to the cost of university also varies with social class background. Students from low social class backgrounds were substantially more likely than their higher-SES counterparts to worry about paying for school. While students of all income levels became more worried about financing their education 
Table 3

Percent of Students (count) from Low-Income Backgrounds* Entering the University of Guelph, and Nineteen Canadian Universities, with the Percent of Canadians with Low Education, 1998

\section{Education (High school or less)}

University of Guelph fathers 27

Fathers at 19 universities 33

Canadian males aged $45-64$ 50

* Based on father's education. high school or less, simlar trends based on mother's education.

Source: Guelph Incoming Student Survey. 1998; Canadian Undergraduate Survey Consortium. 1998 Survey of First-Year Students, average \% from 19 universities.

Table 4

Percent of Guelph Students (count) Concerned About Financing Education by Parental Income

\begin{tabular}{cccc}
\multicolumn{2}{c}{1992} & \multicolumn{2}{c}{1997} \\
Low & High & Low & High \\
$(<\$ 40,000)$ & $(\$ 40,000+)$ & $(<\$ 40,000)$ & $(\$ 40.000+)$
\end{tabular}

$\begin{array}{lllrrr}\text { No concerns } & 12(33) & 29(226) & 8(13) & 27(232) \\ \text { Major concerns } & 27(77) & 12(92) & 39(67) & 16(140)\end{array}$

Source: Guelph Incoming Student Survey, simlar trends based on mother's and father's education. Results significant at $\mathrm{p}<.05$ using chi square. 
between 1992 and 1997, those from low-SES backgrounds consistently worried most. Using both education and income measures, low-SES students were roughly twice as likely to have "major" concerns about financing their education, compared to high-SES students. In 1996 they were nearly one and a half times more likely to view Guelph as "expensive," compared with their high-income counterparts, while in 1993 there was no difference (see Table 5). Further, these students were more likely to cite either financial aid or the cost of attending as an important part of their decision to attend university (see Table 6). In other words, low-SES students were more cost-sensitive than higherSES students.

The higher cost of residential universities, and their effect on student judgements, is suggested by the fact that ratings depended on the availability of a university in their "home" region. The majority of lowincome respondents from regions without a university saw Guelph as less expensive than other Ontario institutions (with the exception of universities in northern Ontario). This response was particularly evident for students from the Toronto area (home to three universities).

Students also differed widely in their use of student assistance (see Table 7). Between 1992 and 1997, students from low-SES families were less likely to receive financial help from their parents, compared to students from higher-SES families. Accordingly they relied more heavily on provincial student loan programs (OSAP). For instance, in 1997, four times as many low-income students (52\%) than higher-income students (14\%) received OSAP (see Table 7). Low-SES students are clearly at a disadvantage when it comes to financing their education; they cannot turn as readily to their parents for money, and must rely more heavily on student loans. Those averse to taking on loans (and subsequent debt) may not be attending Guelph at all. Thus, access to that university may be blocked for those students who are unable to finance their education, or are unwilling to take on high levels of debt. Those who do enrol in the university, though, appear to be able to finance their schooling, since Guelph students from low-SES backgrounds were just as likely as highSES students to finish their degrees. 
Table 5

Percent of Students (count) Admitted to the University of Guelph who Identified "Expensive"** as a Widely-Held Image of Guelph by Parental Income

1993

Low-Income $(<\$ 40,000)$

High-Income $(\$ 40,000+)$
$7 \quad(71)$

7 (244)
1996

$22(256)$

$16(697)$

**Question: Students were asked to identify "expensive" as one of the "most widelyheld images of our university."

Source: Admitted Student Questionnaire 1993 results statistically insignficant; 1996 results significant at $p<.05$ using chi square.

Table 6

Percent of Students (count) Admitted to the University of Guelph who

Reported that either "Aid" or "Cost" was a Significant Factor in their

Decision to Enrol in University** by Parental Income

1993

Low-Income $(<\$ 40,000)$

High-Income $(\$ 40,000+)$
$47(433)$

$30(972)$
1996

55

$33(1,413)$

**Question: "Was either financial aid or the cost of attending a significant factor in your decision to enrol in the university you plan to attend?"

Source: Admitted Student Questionnaire, similar trends based on the proportion of students who rated the net cost of attending university as "very important." Results significant at $\mathrm{p}<.05$ using chi square.

Table 7

\section{Percent of Students (count) Receiving OSAP Loans by Parental Income}

1992
1997

Low-Income $(<\$ 40,000)$

High-Income $(\$ 40,000+)$
$52(89)$

$14(123)$

Source: Guelph Incoming Student Survey, similar trends based on mother's and father's education. Results significant at $p<.05$ using chi square.

The Canadian Journal of Higher Education

Volume XXXII, No. 3, 2002 
In sum, these data reveal that between the late 1980 s and 1990 s, students from low-SES families entered the University of Guelph in smaller proportions. While more data are needed to make definitive conclusions, our evidence shows that rising tuition coincides with a decrease in access. Though a similar disproportion existed at other Canadian universities in 1998, Guelph had become a relatively exclusive institution. Moreover, students from low-SES backgrounds appear to be more costsensitive, and became particularly more concerned about their ability to pay for university. While we do not discount the role of culture in educational decision-making, we conclude that increasing costs present a stark barrier to less affluent students. Students who attend residential institutions may be increasingly the ones who can afford it. To paraphrase John Porter, money still matters.

\section{DISCUSSION: ACCESS IN AN INCREASINGLY STRATIFIED SYSTEM}

As the twenty-first century begins, universities are becoming more entrepreneurial in order to offset uncertainties of government funding and to become more self-reliant. One logical consequence of this is the raising and deregulation of tuition fees. Tuition fees, particularly in Ontario, have risen to unprecedented levels, and the ability to pay these costs is obviously linked to socioeconomic status. Our data show the impact of rising fees on representative attendance at one Ontario residential institution, the University of Guelph, which is more expensive than commuter universities. We argue, however, that this finding is suggestive of a larger trend beyond Guelph's particular case. In the rest of the paper we argue that our finding is indicative of an emerging, more textured process of inequality in higher education.

Before the great expansion of higher education began in the 1950s, universities were relatively elite institutions, with only tiny proportions of the populace attending. Since class disparities in higher education hinged on whether or not students attended any university, researchers used a binary "participation/exclusion" conception of access to postsecondary education (e.g., see the international collection in Shavit \& Blossfeld, 1993). This conception, however, is no longer sufficient, for it 
fails to recognize that more people are now included somewhere in the university system, and that this system is changing. We believe the increasing under-representation of lower SES students at Guelph (a residential institution) and at the University of Western Ontario medical school (a professional school with deregulated tuition) indicates something new. These students may not be forgoing postsecondary education entirely, but rather are being priced out of its more expensive niches. Less affluent youth and adults will likely continue university studies in large numbers, but in the coming era of academic capitalism, they may be sorted into less costly segments of an increasingly stratified postsecondary educational system.

Postsecondary systems in many countries, particularly Canada, long ago made the transition from "elite" to "mass" phases, and may be now entering a "universal" phase in which the majority of incoming youth cohorts attend an institution of higher education (Monks, 2000). As so many graduates crowd today's postsecondary marketplace, their later life chances are crucially influenced not only by whether or not they attend a university, but also by their choice of field of study, and increasingly, their choice of institution. Programs and institutions differ in terms of the economic opportunities they provide. Some fields of study, such as engineering and business, are far more prestigious and lucrative than others such as journalism and education. Students' choices of academic programs or fields of study have far-reaching effects on subsequent earning potential; not all university credentials are equally valued by students nor employers. Because there is a clear ranking of post secondary credentials, educational competition hardly ends when a student enters higher education (Davies \& Guppy, 1997; Davies \& Hammack, 2001). Some credentials are clearly more valuable than others.

Rising tuition, particularly when fees are deregulated, represents a crucial link between the new entrepreneurial forces in academe and emerging forms of stratification in Canadian higher education. Deregulated fees for prestigious degrees are a prime manifestation of academic capitalism because they epitomize market-style thinking in universities. The rationale is to charge whatever the consumer is willing to pay, exploit the intense competition and the higher demand for lucrative 
professional degrees, and make some sub-units within universities financially autonomous. This process is becoming more widespread. In Ontario for instance, institutions such as Queen's University, the University of Toronto, and the University of Western Ontario, have called on the provincial government to deregulate all of their tuition fees and permit them to charge what the market will bear.

This academic capitalism is unleashing a series of forces that may further stratify the university system. Canadian universities are currently not graded by a steep prestige hierarchy as in other nations, such as the United States (Trow, 1991). While a small number of Canadian universities may enjoy more repute than others, the system is not arrayed on a vast, American-style continuum, which ranges from the elite Ivy League to lowly state community colleges. Canada still lacks a national market for undergraduate credentials; most students attend local universities, and few cross provincial borders. But the revenue-generating forces of academic capitalism may change this. If universities are expected to generate their own revenues, whether via large external research grants, corporate funds, alumni donations, and steeper tuition fees, some institutions will clearly be more successful than others. Older and larger research-intensive universities enjoy advantageous resources such as multiple professional schools, and large bodies of wealthy alumni and corporate contacts. These universities will be more likely to attract top faculty, and run generously-endowed academic programs. Gaining prestige, they can raise their admission requirements and compete for the top students by guaranteeing residence for first-year students, and building more on-campus residence spaces, consequently leaving smaller and less wealthy institutions behind.

What is further crucial is whether students and employers will perceive these wealthier institutions as offering a superior education. If so, it may bring an intensified pecking order within the Canadian university sector. In the United States, the most expensive and prestigious institutions largely draw from the academically or economically elite, and offer their graduates far higher incomes than do less renowned universities that house the economically and academically average (Kingston \& Lewis, 1990). Because their credentials are so valued by employers, the 
top American universities enjoy a vaulted market position, and have boosted their tuition fees to astronomical levels without seeing any drop in student applications. The trends in this study may mean that Canadian universities also will become more stratified.

In a more stratified system with tuition fees set by market criteria, the tie between class background and different strata of the system will tighten, pushing people from lower SES backgrounds into lower ranking and less costly programs of study. The University of Western Ontario medical school study represents a telling example of the immediate impact of deregulated tuition upon access and equity. Our data show that less affluent students are more cost sensitive and debt averse, leading us to doubt that they are readily embracing a new "finance model" and are unaffected by high fees, as some policy makers hope. Instead, they appear to be seeking more affordable niches within the system, leaving those degrees that offer the greatest monetary rewards only to those who can assume hefty debt burdens. There may be other unintended effects as well. Women may lose footing as academic capitalism flourishes. While women may continue to comprise the majority of undergraduates, they may be increasingly concentrated in lower-status and lower-funded areas of study, such as education and the humanities (Fisher \& Rubenson, 1998). This stratification will also alter the social experiences of university students. If the more cost-sensitive forego residential institutions, those universities will be increasingly homogeneous, populated by affluent students, leaving commuter institutions with more varied clientele. The latter will have restricted opportunities to attend residential schools, which can offer a rich experience, if not the highest payoffs.

This scenario is speculative, and more research is needed to more fully document and explain these trends. Nevertheless, access to post secondary education today is clearly more intricate than in the past. By raising and/or deregulating their fees, universities and professional schools are passing a larger financial burden on to students. The underlying rationale - that universities should charge what the market will bear - speaks to a trend that may further stratify the Canadian university system, and hinder equitable access to postsecondary education. 


\section{Notes}

l By way of comparison, in the 1960s tuition fees were reluctantly tolerated by universities as a necessary evil. In 1964, while discussing a $\$ 50$ tuition fee increase, the Ontario universities' Committee of Presidents "expressed concern about the social effects of raising the already forbidding financial barrier to higher education" (Fleming, 1971, p. 412).

2 For a summary of international studies, see Shavit \& Blossfeld, 1993. For Canadian examples, see Anisef et al., 2001; Bouchard \& Zhao, 2000; Butlin, 1999; Christofides et al., 2001; Davis, 1984; Gilbert et al., 1993; Guppy \& Arai, 1993; Guppy, Mikicich \& Pendakur, 1984; Guppy \& Pendakur, 1989; McRoberts, 1985; Nakhaie \& Curtis, 1998; Ontario Federation of Students, 1981; Pascal \& Kanowitch, 1979; Pike, 1988, 1970; Porter, 1965; Porter, Porter \& Blishen, 1979, 1982; von Zur-Meuhlen, 1978; Wanner, 1999.

3 Data are based on 1997 earnings for bachelor's graduates of the class of 1995. Graduate school is even more lucrative, with Master's and PhD graduates earning an average salary of $\$ 47,000$ two years after graduation (Bouchard \& Zhao, 2000).

4 Our measures of income have some limitations. Many students are more likely to know their parents' education level than their income, so education is likely a more reliable measure of SES. Further, though our time period was characterized by some wage inflation, we used the same dollar amounts to categorize income. Also, prior to 1994, the question did not allow respondents to reply "Don't Know." After 1994, students who replied "don't know" were excluded.

\section{References}

Anisef, P., Bell, S., \& Sweet, R. (2001). Accessibility and student debt: The shift from public to private support of higher education in Canada. OCUFA Forum, Toronto, ON: Ontario Confederation of University Faculty Associations.

Bouchard, B., \& Zhao, J. (2000). University education: Recent trends in participation, accessibility and returns. Education Quarterly Review, 6(4), Statistics Canada.

Butlin, G. (1999). Determinants of postsecondary participation. Education Quarterly Review, 5(2), Statistics Canada. 
Cameron, D. (1997). Maritime provinces higher education commission MPHEC: Accessibility to postsecondary education. Angus Reid Group, Inc..

Canadian Undergraduate Survey Consortium. (1998). 1998 survey of firstyear university students. Winnipeg, MB: University of Manitoba Housing and Student Life Department.

Canadian Undergraduate Survey Consortium. (1999). 1999 student information survey. Winnipeg, MB: University of Manitoba Housing and Student Life Department.

Christofides, L., Cirello, J., \& Hoy, M. (2001). Family income and postsecondary education in Canada. The Canadian Journal of Higher Education, 23(1).

Clark, W. (1998, Winter) Paying off student loans. Canadian Social Trends. Statistics Canada.

Council of Ontario Universities. (1999). Ontario's students, Ontario's future.

Davies, S. (1999). Stubborn disparities: Explaining class inequalities in schooling. In Curtis et al., (Eds.), Social inequality in Canada: Patterns, problems, policies. $3 r d$ Ed. Scarborough, ON: Prentice-Hall Canada Inc.

Davies, S., \& Hammack, F. (2001). Changing forms of competition in higher education: Comparing Canada and the U.S. For presentation to the American Sociological Association, Anaheim, CA, August 2001.

Davies, S., \& Guppy, N. (1997). Fields of study, college selectivity and student inequalities in higher education. Social Forces, 75(4).

Davis, C. (1984). Accessibility to Ontario universities. Toronto, ON: Council of Ontario Universities.

Delaney, A.M. (1998). Parental income and students' college choice process: Research findings to guide recruitment strategies. Paper presented at the 38th Forum of the Association for Institutional Research, Minneapolis, MN, May $17-20,1998$.

Dill, D. (2001). The regulation of public research universities: Changes in academic competition and implications for university autonomy and accountability. Higher Education Policy, 14(1).

Fine, S. (2001). Medical schools fees exclude poor. The Globe and Mail, April 4.

Fisher, D., \& Rubenson, K. (1998). The changing political economy: The private and public lives of Canadian universities. In J. Currie \& J. Newson (Eds.), Universities and globalization: Critical perspectives. London: Sage Publications.

Fleming, W.G. (1971). Ontario's educative society. Vol. IV: Postsecondary and adult education. Toronto, ON: University of Toronto Press. 
Furlong, A., \& Cartmel, F. (1997). Young people and social change: Individualization and risk in late modernity. Buckingham, UK: Open University Press.

Gilbert, S., Barr, L., Clark, W., Blue, M., \& Sunter, D. (1993). Leaving school: Results from a national survey comparing school leavers and high school graduates 18 to 20 years of age. Ottawa, ON: Statistics Canada.

Guppy, N., \& Arai, B. (1993). Who benefits from higher education? Differences by sex, social class, and ethnicity. In Curtis et al., (Eds.), Social inequality in Canada: Patterns, problems, policies. 2nd ed. Scarborough, ON: Prentice-Hall Canada, Inc.

Guppy, N., \& Davies, S. (1998). Education in Canada: Recent trends and future challenges. Ottawa, ON: Statistics Canada.

Guppy, N., Mikicich, P.D., \& Pendakur, R. (1984). Changing patterns of educational inequality. The Canadian Journal of Higher Education, 14(3).

Guppy, N., \& Pendakur, K. (1989). The effects of gender and parental education on participation within postsecondary education in the 1970 s and 1980s. The Canadian Journal of Higher Education, 19(1).

Heller, D.E. (1997). Student price response in higher education: An update to Leslie and Brinkman. Journal of Higher Education, 68(6).

Ipsos-Reid. (2001). Parents worry about access to postsecondary education. May 7.

Kingston, P., \& Lewis, L.S. (1990). The high status track: Studies of elite schools and stratification. Albany, NY: State University of New York Press.

Little, D. (1997). Financing universities: Why are students paying more? Education Quarterly Review, 4(2), Statistics Canada.

Livingstone, D.W. (1999). The education-jobs gap. Toronto, ON: Garamond.

Marchak, P. (1996). The future of the university... and now a word from our sponsor. Queen's Quarterly, 103(3).

McRoberts, H. (1985). Mobility and attainment in Canada: The effects of origin. In Boyd et al., (Eds.), Ascription and achievement: Studies in mobility and status attainment in Canada. Ottawa, ON: Carleton University Press.

Miller, E. (1997). Parents' views on the value of a college education and how they will pay for it. Journal of Student Financial Aid, 27(1).

Monks, V.L. (2000). Diversity and marketisation of higher education: Incompatible concepts? Higher Education Policy, 12, 23-39.

Nakhaie, M.R., \& Curtis, J. (1998). Effects of class positions of parents on educational attainment of daughters and sons. Canadian Review of Sociology and Anthropology, 35(4). 
Nelson, J. (1995). Post-industrial capitalism: Exploring economic inequality in America. Thousand Oaks, CA: Sage Publications..

Ontario Federation of Students. (1981). A candle in the wind: Postsecondary education in the $80 \mathrm{~s}$. Brief presented to the Committee on the Future Role of Universities in Ontario.

Pascal, C., \& Kanowitch, S. (1979). Student withdrawals from Canadian universities: A study of studies. Toronto, ON: Higher Education Group, Ontario Institute for Studies in Education.

Plager, L., \& Chen, E. (1999). Student debt from 1990-91 to 1995-96: An analysis of Canada student loans data. Education Quarterly Review, 5(4), Statistics Canada.

Pike, R. (1988). Recommendations on access to postsecondary education. In Curtis et al., (Eds.), Social inequality in Canada: Patterns, problems, policies. Scarborough, ON: Prentice-Hall Canada Inc.

Pike, R. (1970). Who doesn't get to university - and why: A study on accessibility to higher education in Canada. Ottawa, ON.

Porter, J. (1965). The vertical mosaic: An analysis of social class and power in Canada. Toronto, ON: University of Toronto Press.

Porter, M., Porter, J., \& Blishen, B. (1973, 1979). Does money matter? Prospects for higher education in Ontario. Toronto, ON: Macmillan Company of Canada.

Schmidt, S. (1998). U of T Takes on tuition fee woes. Varsity News, February 8 , University of Toronto.

Shavit, Y., \& Blossfeld, H.-P. (1993). Persistent inequality: Changing educational attainment in thirteen countries. Boulder, CO: Westview Press.

Slaughter, S., \& Leslie, L. (1997). Academic capitalism: Politics, policies, and the entrepreneurial university. Baltimore, MD: The Johns Hopkins University Press.

Statistics Canada. (1986, 1991, 1996) Census.

Statistics Canada. (1986, 1994). General Social Survey.

Statistics Canada. (1997) University tuition fees. The Daily, August 25.

Statistics Canada. (1998). Education Quarterly Review, 5(2).

Statistics Canada. (1999a). Education Quarterly Review, 6(1).

Statistics Canada. (1999b). University tuition fees. The Daily, August 25.

Statistics Canada. (2000a). Education indicators in Canada 1999. Report of the Pan-Canadian Education Indicators Program, Council of Ministers of Education, Canadian Education Statistics Council.

Statistics Canada. (2000b). University enrolment. The Daily, March 9. 
Statistics Canada. (2000c). University finances. The Daily, July 25.

Statistics Canada. (2001). University tuition fees. The Daily, August 27.

Steelman, L.C., \& Powell, B. (1991). Sponsoring the next generation: parental willingness to pay for higher education. American Journal of Sociology, 96(6).

Sweet, R., Anisef, P., Ng, P., Gallagher, P., \& Davies, S. (2002). Exploring the role of parents in planning for postsecondary education. Report to Council of Ministers of Education, Ottawa, ON.

Trow, M. (1991). The exceptionalism of American higher education. In M. Trow \& T. Nybom (Eds.), Universities and society: Essays on the social role of research and higher education, (pp. 156-172). London: Kingsley Publications.

von Zur-Muehlen, M. (1978). The educational background of parents of postsecondary students in Canada. Institutional and Public Finance Statistics Branch, Statistics Canada.

Wanner, R. (1999). Expansion and ascription: Trends in educational opportunity in Canada, 1920-1994. Canadian Review of Sociology and Anthropology, 36(3). 